\title{
SHORT COMMUNICATION \\ What impedes working in rural areas? A study of aspiring doctors in the National Capital Region, India
}

\author{
NK Saini ${ }^{1}$, R Sharma $^{1}$, R Roy $^{1}$, R Verma $^{2}$ \\ ${ }^{1}$ Department of Community Medicine, University College of Medical Sciences, Delhi, India \\ ${ }^{2}$ Department of Community Medicine, PT BD Sharma Pgims, Rohtak, Haryana, India
}

Submitted: 18 October 2011; Revised: 15 December 2011; Published: 15 March 2012

\section{Saini NK, Sharma R, Roy R, Verma R}

What impedes working in rural areas? A study of aspiring doctors in the National Capital Region, India Rural and Remote Health 12: 1967. (Online) 2012

Available: http://www.rrh.org.au

A B S T R A C T

Introduction: The rural health system in India has long been disadvantaged by a shortage of health staff, including doctors. Providing medical students with a rural clinical placement has been suggested as one strategy to overcome this shortage. This study examined the attitudes of and inclination to rural healthcare careers among medical students.

Methods: A cross-sectional study was performed on 201 students (147 males and 54 females) from two medical colleges in the National Capital Region (NCR) of India. A pre-tested semi-open-ended questionnaire was used to obtain information about students' socio-demographic characteristics and their views about a rural health career. Students' open-ended responses were collated and coded into broad categories.

Results: Of the respondents, $160(79.6 \%)$ had a rural background. The current status of rural health services in India was rated as unsatisfactory by 178 students (88.6\%). In total 110 (54.7\%) indicated an interest in working in a rural area after graduation with 68 (33.8\%) willing to set up their practice in a rural area. Students with a rural background were more likely to be willing to practice in a rural area. Those whose parents were highly qualified (postgraduate education or higher) were significantly less likely to practice in a rural area $(p=0.004)$. Potential benefits of working in a rural area included 'health services for the poor/ benefit for the nation', and 'gain of knowledge about rural people and their diseases'. Potential drawbacks included 'lack of infrastructural facilities', 'less salary' and 'low standard of living'. A majority of the students believe the undergraduate medical curriculum needed modification to improve student awareness of rural needs.

Conclusion: The medical students surveyed had a positive view of the importance of rural health care. However, factors such as infrastructure and salary were perceived as potential barriers to a career in rural health. The findings are a starting point to 
understanding the attitude of medical students towards rural health care and designing specific strategies to overcome the shortage of rural doctors in India.

Key words: barriers, doctors, India, perception, rural workforce shortage.

\section{Introduction}

India's rural health system in has long been disadvantaged by a shortage of health staff, including doctors. Statistics for 2010 suggest a short-fall of $10.3 \%$ for doctors at primary health centers (PHCs) and 62\% for specialists at the secondary level ${ }^{1}$. Many health workers prefer to work in urban areas due to higher incomes, better living conditions and better educational opportunities for their children ${ }^{2}$.

Providing medical students with a rural clinical placement has been suggested as one strategy to familiarize future health professionals with the rural workplace ${ }^{3}$. In India a report by the Bhore Committee directed government attention to establishing a publicly funded and managed health system. The creation of a cadre of basic doctors trained in clinical skills and public health was central to this plan ${ }^{4}$. In addition, the Medical Council of India in consultation with the health ministry devised an alternative model of medical education open only to students who had completed all their school education in villages ${ }^{3}$.

Identifying the attitudes of and intentions towards rural health care among current medical students in India is an important exercise, for they are the health workforce of the near future. This will assist in identifying strategies to increase the quality and quantity of healthcare human resources available to underserved regions of the nation.

\section{Methods}

This cross-sectional study was performed with undergraduate student participants from two medical colleges in the National Capital Region (NCR) of India: the University College of Medical Sciences in Delhi, and the Pt BD Sharma PGIMS, Rohtak in Haryana State. The objective was to check for differences between urban- and rural-origin students. Students in their 6th semester were contacted and informed about the purpose of the study. Participation was voluntary, and anonymity and confidentiality of individual responses were assured.

A pre-tested semi-open-ended questionnaire obtained students' socio-demographic characteristics and their views about rural health care (Appendix I). Open-ended responses were collated and coded into broad categories. Statistical analysis included calculating proportions and applying $\chi^{2}$ tests of significance of association.

The study was reviewed and approved by departmental experts. The institutional ethics committee was not consulted because the study was an anonymous, unlinked interview of respondents and no intervention was involved.

\section{Results}

The total number of respondents was 201, comprising 147 (73.1\%) males. Respondents' mean age was $21.1 \pm 1.1$ years, and 160 (79.6\%) were of rural background. Regarding parental education, 90 fathers $(44.8 \%)$ had post-graduate education or higher, compared with 65 mothers (32.3\%).

Of the total students, $178(88.6 \%)$ rated the current rural health services in India to be unsatisfactory. In total 110 (54.7\%) indicated an interest in working in a rural area for some time after graduation; however, the majority (74; $66.4 \%$ ) were only willing to work in rural areas for a few months to 2 years. In all, $68(33.8 \%)$ said they would be willing to set up their practice in a rural area.

Differences in the characteristics of those willing and those unwilling to practice in rural areas were explored (Table 1). 
Rural-background students were more likely to indicate willingness for rural practice; students whose parents were educationally well qualified were significantly less likely to be ready to practice in rural areas (both $p=0.004$ ). There was no significant association of the responses with gender.

All respondents were asked about potential benefits of working in a rural area (Table 2). The commonest benefit mentioned was 'health services for the poor' (42.3\%) and 'gain of knowledge about rural people and their diseases' (26.9\%). Some students (9.5\%) perceived no apparent benefit. In a subsequent question, students were asked about potential disadvantages of working in a rural area (Table 3). The greatest perceived disadvantage was 'lack of infrastructural facilities' ( $61.2 \%$ ), while 'lack of education opportunities for children' was a concern for 13 respondents (6.5\%).

Approximately two-thirds of the students $(132 ; 65.7 \%)$ had heard about the proposed rural healthcare course. Of these, the majority 92 (69.7\%) had a favorable opinion about its impact on the improvement of rural health care. Of the total students, $43(21.4 \%)$ were preparing (or intended to prepare) for study or work outside India (eg United States Medical Licensing Examination). As can be expected, those preparing to go abroad were significantly less likely than other students to be willing to serve in rural areas $(32.6 \%$ vs $60.8 \%, p=0.001$ ) and to be willing to set up practice in a rural area $(20.9 \%$ vs $37.3 \%, p=0.04)$. A majority of the students $(151 ; 75.1 \%)$ believed the medical curriculum should be modified to make students more aware of the country's needs, especially rural areas.

\section{Discussion}

The provision of rural healthcare services with an adequate, trained health workforce, especially trained doctors, is a large challenge for India. In the present study the majority (88.6\%) of respondents believed that the current status of rural health services was unsatisfactory. Rao et al observed that an acute shortage of health workers in rural areas, particularly physicians, severely constrained rural health services ${ }^{5}$.
Insufficient doctors to staff government healthcare services throughout India has been a matter of government concern for some time 6 . In this study, $54.7 \%$ of the students expressed interest in serving in a rural area for some time after graduation. However, the majority of these were only willing to work in rural areas for a few months to 2 years.

In the present study, rural-background students were more likely to be willing to practice in rural areas than those from urban areas. Similar results have been found in previous studies among various categories of healthcare students ${ }^{7-10}$. It has also been observed that rural placements in undergraduate programs have a positive influence on students' intention to work in a rural community after graduation ${ }^{9-12}$. Motivating factors for rural practice were mainly the altruistic purpose of 'serving the country by serving the poor'. Objective factors were also mentioned and mainly included the personal benefit of gaining knowledge about rural diseases. Almost one-tenth (9.5\%) said they perceived no benefit.

On being asked about the potential disadvantages of working in a rural area, the commonest mentioned were 'lack of infrastructural facilities', 'less salary', 'low standard of living', and 'limited exposure as a doctor'. A previous review produced a similar list of common factors ${ }^{13}$. A study on attracting and retaining doctors in rural Nepal concluded that the government should invest in improving working conditions in rural areas ${ }^{14}$. It has also been observed that recognizing and integrating rural health practitioners with the existing health system in rural areas can be the solution to a shortfall in healthcare personnel ${ }^{15}$. Security concerns were not a major factor among the students.

A strength of the present study is that the opinions of students from both urban and rural backgrounds were investigated. Another was the open-ended design of the questionnaire that permitted qualitative responses. Limitations included the cross-sectional design and that only the current perceptions of the students were studied, which may not reflect their actual, future behavior. A further limitation was that the influence of socio-economic status of the students was not studied. 
Table 1: Differences in the characteristics of the students who expressed willingness to practice in rural areas and those unwilling

\begin{tabular}{|c|c|c|c|}
\hline \multirow[t]{2}{*}{ Characteristic } & \multicolumn{2}{|c|}{$\begin{array}{c}\text { Willingness to practice in rural } \\
\text { area }-n(\%)\end{array}$} & \multirow[t]{2}{*}{$\begin{array}{l}P \text {-value for } \\
\text { difference }\end{array}$} \\
\hline & $\begin{array}{c}\text { Yes } \\
(n=68)\end{array}$ & $\begin{array}{c}\text { No } \\
(n=133)\end{array}$ & \\
\hline Age (years)-mean & 21.2 & 21.0 & 0.13 \\
\hline $\begin{array}{l}\text { Medical college location } \\
\text { Haryana } \\
\text { Delhi }\end{array}$ & $\begin{array}{l}43(41.0) \\
25(26.0)\end{array}$ & $\begin{array}{l}62(59.0) \\
71(74.0)\end{array}$ & $0.03 *$ \\
\hline $\begin{array}{l}\text { Sex } \\
\text { Male } \\
\text { Female }\end{array}$ & $\begin{array}{l}49(33.3) \\
19(35.2)\end{array}$ & $\begin{array}{l}98(66.7) \\
35(64.8)\end{array}$ & 0.81 \\
\hline $\begin{array}{l}\text { Residential status } \\
\text { Living with parents/guardians } \\
\text { Living away from parents/guardians }\end{array}$ & $\begin{array}{l}33(37.9) \\
35(31.0)\end{array}$ & $\begin{array}{l}54(62.1) \\
78(69.0)\end{array}$ & 0.30 \\
\hline $\begin{array}{l}\text { Location of family origin } \\
\text { Urban } \\
\text { Rural }\end{array}$ & $\begin{array}{l}45(28.1) \\
23(56.1)\end{array}$ & $\begin{array}{c}115(71.9) \\
18(43.9)\end{array}$ & $0.001 *$ \\
\hline $\begin{array}{l}\text { Perception of current status of rural hea } \\
\text { in India } \\
\text { Satisfactory } \\
\text { Unsatisfactory }\end{array}$ & $\begin{array}{c}9(40.9) \\
59(33.0)\end{array}$ & $\begin{array}{c}13(59.1) \\
120(67.0)\end{array}$ & 0.46 \\
\hline $\begin{array}{l}\text { Student's state } \\
\text { Haryana } \\
\text { Delhi } \\
\text { Other }\end{array}$ & $\begin{array}{l}46(43.4) \\
11(26.8) \\
11(20.4)\end{array}$ & $\begin{array}{l}60(56.6) \\
30(73.2) \\
43(79.6)\end{array}$ & $0.008 *$ \\
\hline $\begin{array}{l}\text { Father's education level } \\
\leq \text { College graduate } \\
\geq \text { Postgraduate }\end{array}$ & $\begin{array}{l}47(42.7) \\
21(23.3)\end{array}$ & $\begin{array}{l}63(57.3) \\
69(76.7)\end{array}$ & $0.004 *$ \\
\hline $\begin{array}{l}\text { Mother's education level } \\
\leq \text { College graduate } \\
\geq \text { Postgraduate }\end{array}$ & $\begin{array}{l}55(40.7) \\
13(20.0)\end{array}$ & $\begin{array}{l}80(59.3) \\
52(80.0)\end{array}$ & $0.004 *$ \\
\hline
\end{tabular}

$*$ Statistically significant difference at $<0.05$

Table 2: Potential benefits of working in a rural area as perceived by the students $(n=201)$

\begin{tabular}{|c|c|}
\hline Potential benefit & $n^{\dagger}(\%)$ \\
\hline Health services for the poor / serving the country & $85(42.3)$ \\
\hline Gain knowledge about rural people and diseases & $54(26.9)$ \\
\hline No benefits & $19(9.5)$ \\
\hline Satisfaction & $16(8.0)$ \\
\hline Easy/ stress-free life & $15(7.5)$ \\
\hline Being respected as a doctor & $8(4.0)$ \\
\hline Career opportunities greater ( less competition) & $6(3.0)$ \\
\hline
\end{tabular}


Table 3: Potential drawbacks of working in a rural area as perceived by the students $(n=201)$

\begin{tabular}{|l|c|}
\hline Potential drawback & $\boldsymbol{n}^{\dagger} \mathbf{( \% )}$ \\
\hline Infrastructure facilities are absent & $123(61.2)$ \\
\hline Lower salary & $33(16.4)$ \\
\hline Low standard of living & $28(13.9)$ \\
\hline Limited professional experience & $25(12.4)$ \\
\hline Lack of sanitation & $14(7.0)$ \\
\hline Lack of education opportunities for children & $13(6.5)$ \\
\hline Limited technology & $10(5.0)$ \\
\hline Lack of recreational facilities & $6(3.0)$ \\
\hline Absenteeism of support staff & $5(2.5)$ \\
\hline None & $3(1.5)$ \\
\hline Security issues & $2(1.0)$ \\
\hline Housing substandard & $2(1.0)$ \\
\hline Have to live away from own family & $2(1.0)$ \\
\hline Possible effects on own health/ illnesses & $2(1.0)$ \\
\hline$\dagger$ Multiple responses permitted. &
\end{tabular}

\section{Conclusion}

Bringing qualified health workers to rural, remote, and underserved areas is a challenging task which needs to be undertaken on a priority basis. Overall, the attitude of the medical students towards the importance of rural health care is positive. However, perceived factors such as infrastructure and salary emerged as potential barriers to students opting for a career in rural health. These findings represent a starting point for understanding the attitude of medical students to rural health care and suggestion the design of specific strategies to overcome the shortage of rural doctors in India.

\section{References}

1. Ministry of Health \& Family Welfare, Government of India. Rural health statistics in India 2010. (Online) 2010. Available: http: / /nrhm-mis.nic.in/UI/RHS/RHS\%202010/RHS\%202010/ Key\%20Highlights\%20from\%20Rural\%20Health\%20Statistics\%20 in\%20India.pdf (Accessed 9 February 2012).
2. Raha S, Berman P, Saran I, Verma T, Bhatnagar A, Awasthi S et al. Career preferences of medical and nursing students in Uttar Pradesh: a qualitative analysis. New Delhi: PHFI and World Bank, 2009.

3. Mudur G. India decides to train non-medical rural healthcare providers. BMJ 2010; 340: c817.

4. Government of India. Report of the Health Survey and Development Committee, vol. 1. Delhi: Manager of Publications, 1946.

5. Rao KD, Gupta G, Jain K, Bhatnagar A, Sundararaman T, Kokho $\mathrm{P}$ et al. Which doctor for primary health care? An Assessment of primary health care providers in Chhattisgarh, India. New Delhi: Public Health Foundation of India, 2010.

6. Datta KK. Public health workforce in India: career pathways for public health personnel. Geneva: WHO, 2009.

7. Oripin $P$, Gabriel M. Recruiting undergraduate to rural practice: what the student can tell us. Rural Remote Health 5: 412. (Online) 2005. Available: www.rrh.org.au (Accessed 16 January 2012). 
8. Wheat JR, Leeper JD, Brandon JE, Guin SM, Jackson JR. The rural medical scholars program study: data to inform rural health policy. Journal of American Board of Family Medicine 2011; 24(1): 93101.

9. Dunbabin JS, Levitt L. Rural origin and rural medical exposure: their impact on the rural and remote medical workforce in Australia. Rural Remote Health 3: 212. (Online) 2003. Available: www.rrh.org.au (Accessed 16 January 2012).

10. Laven G, Wilkinson D. Rural doctors and rural backgrounds: how strong is the evidence? A systematic review. Australian Journal of Rural Health 2003;11(6):277-84.

11. Ranmuthugala G, Humphreys J, Solarsh B, Walters L, Worley $\mathrm{P}$, Wakerman J et al. Where is the evidence that rural exposure increases uptake of rural medical practice? Australian Journal of Rural Health 2007; 15(5): 285-288.
12. Dalton LM, Routley GK, Peek KJ. Rural placements in Tasmania: do experiential placements and background influence undergraduate health science student's attitudes toward rural practice? Rural Remote Health 8: 962. (Online) 2008. Available: www.rrh.org.au (Accessed 16 January 2012).

13. Wilson NW, Couper ID, De Vries E, Reid S, Fish T, Marais BJ. A critical review of interventions to redress the inequitable distribution of healthcare professionals to rural and remote areas. Rural Remote Health 9: 1060. (Online) 2009. Available: www.rrh. org.au (Accessed 16 January 2012).

14. Shankar PR. Attracting and retaining doctors in rural Nepal. Rural Remote Health 10: 1420. (Online) 2010. Available: www.rrh.org.au (Accessed 16 January 2012).

15. Yadav K, Jarhyan P, Gupta V, Pandav CS. Revitalizing rural health care delivery: can rural health practitioners be the answer? Indian Journal of Community Medicine 2009; 34: 3-5. 


\section{Riural-and-Remote-Health}

The International Electronic Journal of Rural and Remote Health Research, Education Practice and Policy

Appendix I: Survey instrument used in the study

Questionnaire used in the study

1. Semester: 2. Age: years
Institute:

3. Sex: Male/Female 4. Religion:

5. Residential Status: a) Living with parents orguardians/b) Living away from parents or guardians

6. State you belong to: 7. Type of area your family belongs to: Urban / Rural

8. Education of Father: 9. Education of Mother:

F. What are the potential drawbacks of working in a rural area?

G. What incentives should the Government provide to doctors working in rural areas?

H. What steps should the Government take to improve rural health care in India?

I. Have you heard about the new Bachelor of Rural Health Care course? Yes/ No

J. In your opinion, is this scheme going to improve rural health services? Yes/ No

K. What are the potential benefits of this scheme?

L. What are the potential drawbacks of this scheme?

M. Are you preparing (or will you prepare) for going out of India to study or work (e.g. USMLE etc.)? Yes/No

N. Do you feel that ourMBBS curriculum needs to be modified to make the students more aware about the needs of our country especially rural areas? Yes/ No 